\title{
31. SR-ND-PB ISOTOPE GEOCHEMISTRY OF LEG 144 WEST PACIFIC GUYOTS: IMPLICATIONS FOR THE GEOCHEMICAL EVOLUTION OF THE "SOPITA" MANTLE ANOMALY"
}

\author{
Anthony A.P. Koppers, ${ }^{2}$ Hubert Staudigel, ${ }^{2}$ David M. Christie, ${ }^{3}$ Julie J. Dieu, ${ }^{4}$ and Malcolm S. Pringle ${ }^{2}$
}

\begin{abstract}
The $\mathrm{Sr}, \mathrm{Nd}$, and $\mathrm{Pb}$ isotopic compositions of five Cretaceous guyots (Limalok, Lo-En, Wodejebato, MIT, and Takuyo-Daisan) within the West Pacific Seamount Province (WPSP) indicate that they originated from geochemically enriched mantle sources. They are characterized by large isotopic variations in $\mathrm{Pb}\left(206 \mathrm{~Pb} / 204 \mathrm{~Pb}=18.58-19.80,{ }^{207} \mathrm{~Pb} / 204 \mathrm{~Pb}=15.55-15.68\right.$, and $\left.{ }^{208} \mathrm{~Pb} / 204 \mathrm{~Pb}=38.68-39.54\right)$ and by moderate variations in $\mathrm{Sr}\left({ }^{87} \mathrm{Sr} /{ }^{86} \mathrm{Sr}=0.70308-0.70486\right)$ and $\mathrm{Nd}\left({ }^{143} \mathrm{Nd} /{ }^{144} \mathrm{Nd}=0.51267-\right.$ 0.51307). Data from the Cretaceous guyots studied are within the overall isotopic range of the WPSP and are similar to those of oceanic basalts produced by currently active hotspots of the South Pacific isotopic and thermal anomaly (SOPITA). The WPSP basalts show a large isotopic variance, and they include samples with isotopic signatures of either enriched mantle sources (EMI and EMII), or mantle sources high in ${ }^{206} \mathrm{~Pb} / 204 \mathrm{~Pb}$ and low in ${ }^{87} \mathrm{Sr} /{ }^{86} \mathrm{Sr}$ (HIMU). These observations suggest that the WPSP and SOPITA basaltic rocks may have been produced from the same heterogeneous mantle source: either one that is isotopically distinct and more diverse from other oceanic and continental volcanic regions, or one that is produced by mixing the different mantle components inferred for these other regions.

We strengthen previous arguments for the longevity of the isotopically unusual character of the SOPITA hotspots, in particular, for the Rurutu-Ratak-Marcus-Wake Seamount Chain (RRMW). Our data from the WPSP doubles the existing database and allows us to examine the temporal isotopic evolution of the RRMW Chain over a total time span of $110 \mathrm{~m} . \mathrm{y}$., excluding the time period between 25 and $50 \mathrm{Ma}$ that has not been sampled yet. The RRMW isotopic data suggest that (1) the overall isotopic variance is constant over time: (2) the $\mathrm{Sr}$ and $\mathrm{Nd}$ variances are smaller than the total variance for the SOPITA and WPSP, whereas the $\mathrm{Pb}$ compositions show similar, large variances; and (3) the isotopic composition of the SOPITA, and specifically the Rurutu volcanics, gradually changed within the last $25 \mathrm{~m} . \mathrm{y}$. from a mantle source dominated by the HIMU mantle component to an EM-type mantle source. The latter is indicated by a decrease in ${ }^{200} \mathrm{~Pb} /{ }^{204} \mathrm{~Pb}, \Delta 7 / 4 \mathrm{~Pb}$, and $\Delta 8 / 4 \mathrm{~Pb}$ paralleled by an increase in ${ }^{87} \mathrm{Sr} /{ }^{86} \mathrm{Sr}$. A similar evolution in isotopic composition may also be revealed from the Ratak-Marcus-Wake Chain over the period from 90 through $70 \mathrm{Ma}$, although this latter trend is obscured by a less dense sampling in the WPSP area.
\end{abstract}

\section{INTRODUCTION}

The mantle underneath the French Polynesian region in the South Pacific (Fig. 1) is both thermally and isotopically unusual (Smith et al., 1989; Staudigel et al., 1991). Within the last 20 m.y., eight currently active South Pacific hotspots have produced an anomalously large number of seamounts (Duncan and Clague, 1985; Bemis and Smith, 1993) on relatively thin and hot oceanic lithosphere of the South Pacific Superswell (McNutt and Fischer, 1987). Basalts erupted from these hotspot volcanoes display an unusually large diversity in isotope ratios and trace-element enrichment history when compared with any other ocean-island province (e.g., Vidal et al., 1984; Zindler and Hart, 1986; Wright and White, 1987; Staudigel et al., 1991; Chauvel et al., 1992; Woodhead and Devey, 1993). In fact, the $\mathrm{Sr}-\mathrm{Nd}-\mathrm{Pb}$ isotope compositions of ocean-island basalts in this South Pacific isotopic and thermal anomaly (SOPITA) cover the entire range between the three major, global mantle components that separate the total field of ocean-island basalts from depleted mid-ocean-ridge basalts: HIMU, EMI, and EMII (Zindler and Hart, 1986; Fig. 2A).

Tubuai and Mangaia ocean-island basalts (Rurutu hotspot) and xenoliths sampled at Tubuai display the highest ${ }^{206} \mathrm{~Pb} / 204 \mathrm{~Pb}$ at low

'Haggerty, J.A., Premoli Silva, 1., Rack, F., and McNutt, M.K. (Eds.), 1995. Proc. ODP, Sci. Results, 144: College Station, TX (Ocean Drilling Program).

Laboratory of Isotope Geology, Vrije Universiteit Amsterdam, De Boelelaan 1085. 1081 HV Amsterdam, The Netherlands.

COAS, Oregon State University, Corvallis, OR 97331, U.S.A.

'Geological Research Division, Scripps Institution of Oceanography, La Jolla, CA 92093, U.S.A.
${ }^{87} \mathrm{Sr} /{ }^{86} \mathrm{Sr}$ and moderately low ${ }^{143} \mathrm{Nd} /{ }^{144} \mathrm{Nd}$ (Palacz and Saunders, 1986; Hauri et al., 1993). They define the HIMU (high $\mu=$ high ${ }^{238} \mathrm{U} / 204 \mathrm{~Pb}$ ) mantle component that is enriched in $\mathrm{Pb}$ isotopes but has a depleted signature for $\mathrm{Sr}$ and $\mathrm{Nd}$. A group of Pitcairn basalts has intermediate ${ }^{87} \mathrm{Sr} /{ }^{86} \mathrm{Sr}$, low ${ }^{143} \mathrm{Nd} /{ }^{144} \mathrm{Nd}$, and high ${ }^{207} \mathrm{~Pb} / 204 \mathrm{~Pb}$ and ${ }^{208} \mathrm{~Pb} / 204 \mathrm{~Pb}$ at low ${ }^{206} \mathrm{~Pb} /{ }^{204} \mathrm{~Pb}$. Within the Pacific basin, these Pitcairn basalts represent the closest approach to the isotopic composition of the EMI mantle component (Enriched Mantle I; Woodhead and Devey, 1993) that is defined worldwide by more extreme Walvis Ridge basalts (Zindler and Hart, 1986). Enriched Mantle II (EMII), the third mantle component, has been recently better defined by the isotopic compositions of Samoan xenoliths (Hauri et al., 1993). It has similar $\mathrm{Pb}$ isotopic ratios to EMI but much higher ${ }^{87} \mathrm{Sr} /{ }^{86} \mathrm{Sr}$ and somewhat lower ${ }^{143} \mathrm{Nd} / 144 \mathrm{Nd}$. The occurrence of the EMII isotopic signature in volcanic rocks partly delineates the Southern Hemisphere DUPAL anomaly (Fig. 1), as was defined by Hart (1984) on its positive deviations in ${ }^{207} \mathrm{~Pb} / 204 \mathrm{~Pb}$ and ${ }^{208} \mathrm{~Pb} / 204 \mathrm{~Pb}$ from the Northern Hemisphere Reference Line (NHRL) for a given ${ }^{206} \mathrm{~Pb} / 204 \mathrm{~Pb}$. Although the SOPITA lies within the DUPAL anomaly (Fig. 1), it is a distinct region of the DUPAL because of its anomalous thermal conditions and because of the strong geochemical contribution from HIMU, which is not seen in the remainder of the DUPAL.

The distinct thermal and isotopic signatures of the SOPITA allow us to trace back into time and to study the long-term evolution of this specific portion of the South Pacific mantle as far as the Cretaceous. Unusual thermal lithospheric conditions of the SOPITA are clearly traced back into the Cretaceous part of the West Pacific Seamount Province (WPSP; see Fig. 1). This Cretaceous region stretches out in a 3000-km-wide area of the West Pacific basin, including multiple seamount chains, clusters of seamounts, scattered individual sea- 


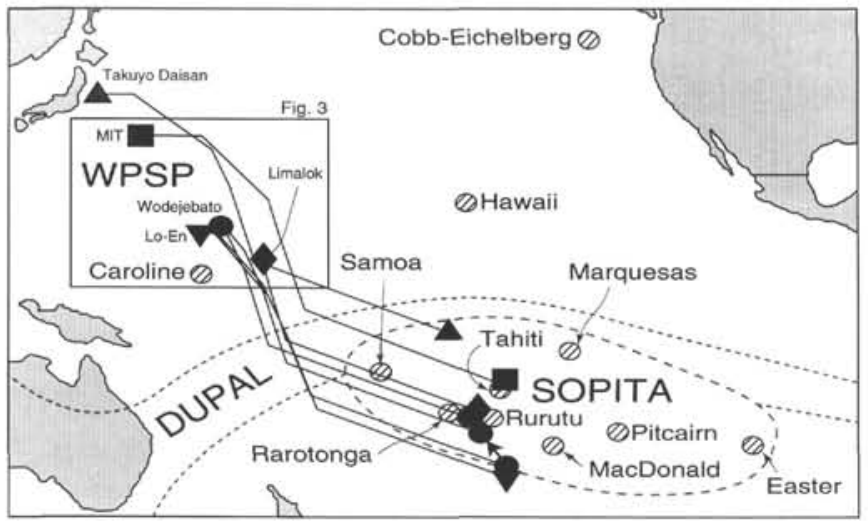

Figure 1. Present-day locations and original locations of eruption (i.e., hotspot locations) of the guyots studied in the West Pacific Seamount Province (WPSP) with respect to the South Pacific isotopic and thermal anomaly (SOPITA; Staudigel et al., 1991) and the DUPAL anomaly (Hart, 1984). In general, the reconstructed hotspot locations of the Limalok, Lo-En, Wodejebato, MIT, and Takuyo-Daisan guyots are backtracked to the SOPITA region. Table 1 summarizes the age data, present-day locations, and locations of eruption, as well as reported paleolatitudes that also indicate an origin of these guyots at latitudes similar to that of the SOPITA region. The plate tectonic reconstruction paths were calculated using the stage poles of Duncan and Clague (1985) and ${ }^{40} \mathrm{Ar} /{ }^{39} \mathrm{Ar}$ ages (Table 1). For Wodejebato, we use the oldest age determined (apron Hole 869 ) because this most likely approximates its shield-building stage. For reference, the currently active hotspots of the SOPITA region are drawn in shaded circles. A detailed explanation on the plate tectonic reconstruction calculations and a discussion on the age data is given by Pringle et al. (this volume). Map revised from Staudigel et al. (1991).

mounts, and oceanic plateaus (e.g., Fig. 3). The WPSP is characterized by an unusually shallow seafloor (Menard, 1964) and an unusually large number of intraplate volcanic edifices formed between 138 and $\sim 60 \mathrm{Ma}$ (Lincoln et al., 1993). Plate tectonic reconstructions of the Pacific region indicate that the WPSP lithosphere originated above the SOPITA region of the deeper mantle (e.g., Duncan and Clague, 1985; Bergersen, this volume), an observation confirmed by southern paleolatitude measurements (Premoli Silva, Haggerty, Rack, et al., 1993; Winterer et al., 1993). Further, the WPSP also has similar thermal characteristics to the SOPITA: (1) thin elastic plate thicknesses of $<15 \mathrm{~km}$ (McNutt and Fischer, 1987; Wolfe and McNutt, 1991); (2) slower than normal subsidence of the lithosphere (Menard, 1964; Smith et al., 1989); and (3) repeated uplift and rejuvenation of the lithosphere over a period of $\sim 70$ m.y. (Smith et al., 1989; Lincoln et al., 1993; Premoli Silva, Haggerty, Rack, et al., 1993; Winterer et al., 1993). The mantle source of the WPSP is also identified as a Cretaceous isotopic equivalent of the SOPITA (Smith et al., 1989; Staudigel et al., 1991).

On the one hand, linear seamount chains formed by SOPITA hotspots over the last $138 \mathrm{~m} . \mathrm{y}$. record the motion and velocity of the Pacific Plate as well as the activity of the SOPITA mantle over time. On the other hand, the presence of such a long-lived anomalous mantle source provides us with an elementary tool to study the evolution of the SOPITA mantle source as part of Earth's dynamic and geochemical system. Thus, records of ages and isotopic compositions along linear seamount chains in the Pacific basin are important in determining, for example, time scales, length scales, spatial variability, continuity, and geochemical evolution of the SOPITA mantle source.

Ocean Drilling Program (ODP) Leg 144 and the TUNES6 expedition of the Scripps Institution of Oceanography (SIO) were conducted to compare mantle source compositions of the Cretaceous WPSP lavas with those of present-day SOPITA and DUPAL lavas. In this paper, we report $\mathrm{Sr}, \mathrm{Nd}$, and $\mathrm{Pb}$ isotope ratios of alkalic basalts
A

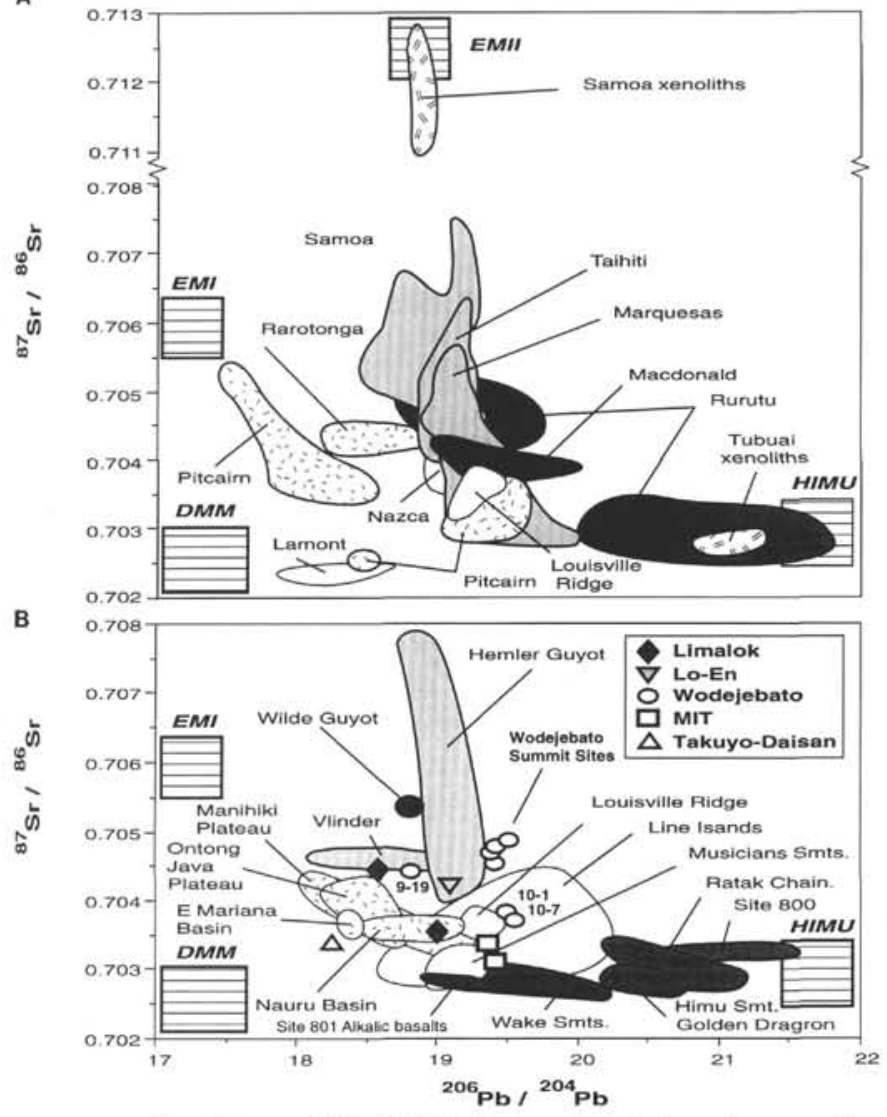

Figure 2. ${ }^{87} \mathrm{Sr} / 86 \mathrm{Sr}$ vs. ${ }^{143} \mathrm{Nd} /{ }^{144} \mathrm{Nd}$ isotope correlation diagrams for ocean-island basalts of the Pacific Ocean. We compare the isotope systematics of the Cretaceous WPSP (lower diagram) with the inferred mantle components DMM, HIMU, EMI, EMII, and PREMA, and its presumed presentday equivalent (SOPITA; Fig. 2A). The composition of the inferred mantle end-members DMM and HIMU are after Zindler and Hart (1986). The EMI end-member for the Pacific Ocean is based on current Pitcairn isotope data of Woodhead and Devey (1993), whereas EMII is based on isotope data from mantle xenoliths sampled at Savai'i (Samoa) after Hauri et al. (1993). A. Isotopic reference fields for the SOPITA and other Cenozoic seamount regions in the Pacific. Sources are Zindler and Hart (1986), Staudigel et al. (1991), McDonough and Chauvel (1991), Chauvel et al. (1992), Farley et al. (1992), Dupuy et al. (1993), Hauri and Hart (1993), Hauri et al. (1993), Woodhead and Devey (1993), and Woodhead et al. (1993). Dark-shaded fields $=$ Cook/ Austral hotspots; light-shaded fields = northern SOPITA hotspots; confetti pattern $=$ Pitcairn and Rarotonga; birds' feet pattern $=$ peridotite xenoliths (Hauri et al., 1993). B. Isotopic reference fields for the Cretaceous WPSP. Symbols indicate analyzed samples (this study), which are explained in the legend. Sources are Mahoney (1987), Smith et al. (1989), Staudigel et al. (1991), Mahoney and Spencer (1991), Castillo et al. (1991, 1992), Pringle (1992), Garcia et al. (1993), Mahoney et al. (1993a, 1993b), and H. Staudigel (unpubl. data). Dark-shaded field and symbols $=$ Ratak-Marcus-Wake Chain (see Fig. 3); light-shaded field and symbols = seamounts erupted near or in the Ogasawara Fracture Zone (see Fig. 3). 10-1 = Sample TUNES6 10-1, 10-7 = Sample TUNES6 10-7, and 9-19 = Sample TUNES6 9-19.

from these expeditions to the Marshall Islands, the Marcus-Wake Chain, and the Japanese Seamounts. The main objectives of this study were (1) to determine the isotopic composition of the mantle source underneath the WPSP, comparing our results with previous work on these Cretaceous seamounts; (2) to compare WPSP isotope systematics with those of the present-day SOPITA mantle source; and (3) to examine and discuss the evolution of the isotope geochemistry of the South Pacific isotopic and thermal anomaly from the Early Cretaceous until the present day. 


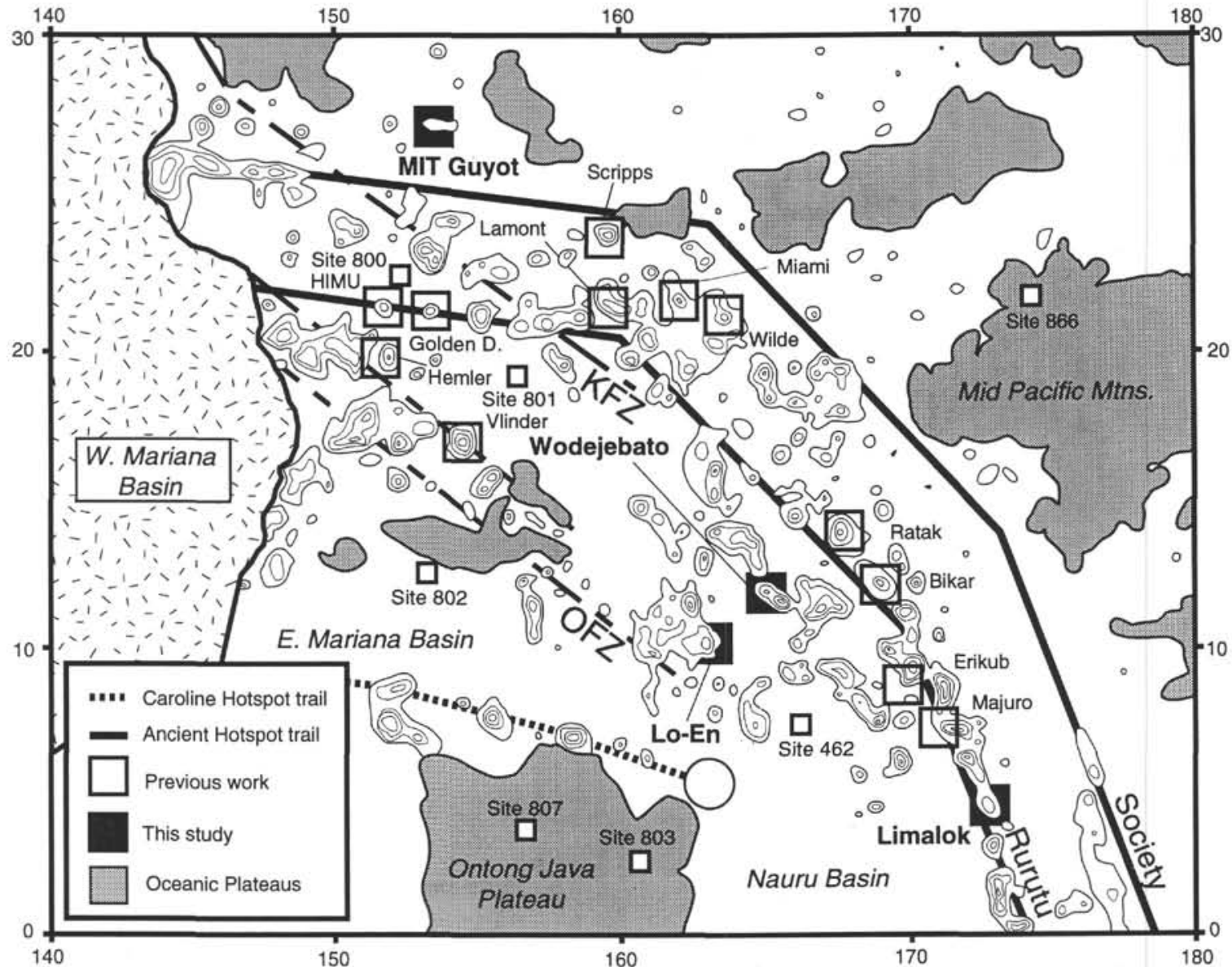

Figure 3. Regional bathymetric map of the Marshall, Marcus-Wake, and Magellan seamount regions, with locations of edifices (previously) analyzed for their $\mathrm{Sr}, \mathrm{Nd}$, and $\mathrm{Pb}$ isotope compositions (= thick-lined squares): (1) Limalok, Lo-En, Wodejebato, and MIT guyots (this study); (2) Hemler, Himu, Golden Dragon, Lamont, Scripps, Miami, Wilde, Ratak, Bikar, Erikub, and Majuro seamounts (Smith et al., 1989; Staudigel et al., 1991); and (3) Vlinder (H. Staudigel, unpubl. data). The location of Takuyo-Daisan Guyot (this study; $34^{\circ} 13^{\circ} \mathrm{N}, 144^{\circ} 19^{\circ} \mathrm{E}$ ) is given in Figure 1 . Stationary hotspot paths of the currently active Rurutu and Tahiti hotspots are drawn as thick, grayish lines after Bergersen (this volume), using stage poles of Duncan and Clague (1985). For completeness, the Caroline hotspot trail has been drawn (thick, broken, dark-grayish line). The zone within the dashed lines gives the location of the Ogasawara Fracture Zone (OFZ), which may have been the locus of mid-Cretaceous volcanism producing Hemler, Vlinder, Ita Mai Tai, Anewetak, and Lo-En (Abrams et al., 1993). KFZ = Kashima Fracture Zone.

\section{SAMPLES STUDIED}

Five guyots were drilled during Leg 144: three in the Marshall Islands (Limalok, Lo-En, and Wodejebato), one in the Marcus-Wake Chain (MIT), and one in the Japanese Seamounts (Takuyo-Daisan). In addition, during the TUNES6 cruise, two dredges were placed north-northeast of Wodejebato Guyot. Sampling locations, original locations of eruption, paleolatitudes, and ages are summarized in Table 1 and Figure 1. Dredge setting and petrography are listed in Table 2. The regional bathymetric map of the Marshall Islands and Marcus-Wake Chain (Fig. 3) also displays those seamounts from which lavas previously have been analyzed for their isotope compositions (Smith et al., 1989; Staudigel et al., 1991).

The Marshall Islands include two parallel, north-northwest-trending chains: the western Ratak and eastern Ralik chains. An isolated, third group of seamounts forms the Ujlan-Anewetak cluster located east of the Ralik Chain. The western part of this cluster, however, partly contains a seamount chain (including Lo-En Guyot) that is parallel to the Ralik and Ratak chains. The Ratak Chain, including Limalok Guyot, seems to continue from Wilde Guyot into the west-northwest-trending Marcus-Wake Chain, extending for $~ 2500$ $\mathrm{km}$ and terminating at the East Mariana Trench. Lo-En Guyot, which is part of the Ujlan-Anewetak cluster, may be partly formed or influ- enced by the volcanic activity associated with the Ogasawara Fracture Zone (Abrams et al., 1993; see Fig. 3). The Takuyo-Daisan and MIT guyots were both formed to the northeast of the Kashima Fracture Zone (Abrams et al., 1993). The former guyot is part of the less pronounced Japanese Seamount Chain, which is oriented parallel to the Marcus-Wake Chain but located $8^{\circ}$ to the north of it; the latter forms a solitary guyot in between the Japanese and Marcus-Wake seamount chains (Fig. 3).

In general, the basaltic rocks of the seamounts studied have alkalic compositions, ranging from mildly alkalic basalts and hawaiites to strongly alkalic basanite and nephelinites (Premoli Silva, Haggerty, Rack, et al., 1993; Winterer et al., 1993; Christie et al., this volume; Dieu, this volume). The Cretaceous WPSP guyots studied were formed on a 140- to 170-m.y.-old Pacific lithosphere over a time period of nearly 50 m.y. (Premoli Silva, Haggerty, Rack, et al., 1993). Radiometric ages of Marshall Islands lavas are typically Late Cretaceous (60-90 Ma: Pringle and Staudigel, 1992), whereas the Marcus-Wake and Japanese seamount groups fall in the range of 82-100 and 94-109 Ma, respectively (Ozima et al., 1983; Winterer et al., 1993). Plate tectonic reconstructions based on these age ranges place the eruption sites for these WPSP seamounts within the present-day SOPITA region (Fig. 1; for a discussion, see Pringle and Duncan, this volume). 
Table 1. Sample locations, locations of eruption, paleolatitudes, and ages of Cretaceous seamounts studied.

\begin{tabular}{|c|c|c|c|c|c|c|c|c|}
\hline \multirow[b]{2}{*}{ Sample } & \multirow{2}{*}{$\begin{array}{c}\text { Age } \\
\text { (Ma) }\end{array}$} & \multirow[b]{2}{*}{ Source } & \multicolumn{2}{|c|}{ Present-day location } & \multirow{2}{*}{$\begin{array}{c}\text { Depth } \\
\text { (m) }\end{array}$} & \multirow[b]{2}{*}{ Paleolatitude } & \multicolumn{2}{|c|}{ Location of eruption } \\
\hline & & & Latitude & Longitude & & & Latitude & Longitude \\
\hline \multicolumn{9}{|l|}{ Marshall Islands: } \\
\hline Limalok & 62 & 1 & $5^{\circ} 33 \uparrow \mathrm{N}$ & $172^{\circ} 20 \mathrm{E}$ & 1500 & $-10^{\circ} \mathrm{S}$ & $22^{\circ} 61^{\prime} \mathrm{S}$ & $153^{\circ} 39^{\prime} \mathrm{W}$ \\
\hline $\begin{array}{l}\text { Lo-En } \\
\text { Wodejebato }\end{array}$ & 113 & 1 & $10^{\circ} 07 \mathrm{~N}$ & $162^{\circ} 48 \mathrm{E}$ & 1080 & $-30^{\circ} \mathrm{S}$ & $33^{\circ} 31^{\prime} \mathrm{S}$ & $147^{\circ} 14^{\prime} \mathrm{W}$ \\
\hline Site 869 hyaloclastites & 96 & 2 & $11^{\circ} 00 \mathrm{~N}$ & $164^{\circ} 45^{\prime} \mathrm{E}$ & 4800 & \multirow{3}{*}{$\sim 10^{\circ} \mathrm{S}$} & $30^{\circ} 74 \mathrm{~S}$ & $148^{\circ} 21 \mathrm{~W}$ \\
\hline Main edifice & 85 & 2 & $12^{\circ} 00 \mathrm{~N}$ & $164^{\circ} 90^{\prime} \mathrm{E}$ & 1350 & & $25^{\circ} 20^{\prime} \mathrm{s}$ & $152^{\circ} 3 \mathrm{I}^{\mathrm{W}} \mathrm{W}$ \\
\hline Northeast satellite volcano & 78 & 2 & $12^{\circ} 06 \mathrm{~N}$ & $164^{\circ} 75^{\prime} \mathrm{E}$ & 3000 & & $22^{\circ} 23^{\circ} \mathrm{S}$ & $155^{\circ} 31^{\mathrm{W}} \mathrm{W}$ \\
\hline Marcus-Wake Seamounts: & 123 & 2 & $27^{\circ} 19^{\prime} \mathrm{N}$ & $151^{\circ} 53^{\prime} \mathrm{E}$ & 1400 & \multirow[t]{3}{*}{$\sim 10^{\circ} \mathrm{S}$} & $16^{\circ} 26^{\prime} \mathrm{S}$ & $149^{\circ} 93^{\prime} \mathrm{W}$ \\
\hline Japanese Seamounts: & & & & & & & & \\
\hline Takuyo-Daisan & 118 & 1 & $34^{\circ} 13^{\prime} \mathrm{N}$ & $144^{\circ} 19^{\circ} \mathrm{E}$ & 1550 & & $8^{\circ} 50^{\circ} \mathrm{S}$ & $158^{\circ} 89 \mathrm{~W}$ \\
\hline
\end{tabular}

Note: Sources are as follows: 1 = Pringle and Duncan (this volume) and 2 = Pringle et al. (1993). Paleolatitudes after Premoli Silva, Haggerty, Rack, et al. (1993).

\section{Limalok Guyot}

Site 871 was drilled during Leg 144 on the southern rim of the volcanic platform of Limalok Guyot, at the south-southeast end of the Ratak Chain. Within Hole $871 \mathrm{C}$, below a claystone unit whose presence appears to be indicative of subaerial weathering, a sequence of at least 23 igneous units was recovered (Premoli Silva, Haggerty, Rack, et al., 1993). Several of the igneous units are volcaniclastic deposits, but the majority are thick flows of basanitic liquids that most reasonably represent posterosional volcanism. Limalok started submerging in the beginning of the late Paleocene ( $62 \mathrm{Ma})$, as indicated by the presence of pristine, gray, calcareous clays bearing nannofossils (Premoli Silva, Haggerty, Rack, et al., 1993). Based on this minimum "sedimentary" age, plate tectonic reconstructions show that Limalok Guyot probably originated in between the present-day Rurutu or Rarotonga hotspots of the Cook/Austral Seamount Chain in the SOPITA region (Fig. 1). In fact, Bergersen (this volume) reconstructed the path of the Rurutu hotspot, which precisely follows the south-southeast end of the Ratak Chain between 65 and $74 \mathrm{Ma}$ (Fig. 3 ), strongly suggesting that the Rurutu hotspot produced Limalok Guyot.

Samples 144-871C-35R-1, 41-43 cm, and -38R-6, 39-43 cm, used for isotopic analyses, are representative of igneous Units 1 and 19 , respectively. Unit 1 is a 50 -cm-thick basanitic flow with abundant calcite veins (1-2 mm thick), whereas Unit 19 is a more massive basanitic flow. Both basanitic lavas contain unaltered, subhedral phe- nocrysts of fresh Ti-augite, and pseudomorphs after olivine. Their microcrystalline groundmass consists mainly of abundant fresh Ti-augite, magnetite, and interstitial plagioclase. Olivine phenocrysts and groundmass grains have been replaced with green and brown clays, chlorite, calcite, and iddingsite. Also, significant clay replacement of groundmass plagioclase and interstitial material has occurred (Premoli Silva, Haggerty, Rack, et al., 1993).

\section{Lo-En Guyot}

Lo-En Guyot is located in the Ujlan-Anewetak cluster close to Anewetak Atoll (Fig. 3), and it submerged by $112.8 \pm 1.2 \mathrm{Ma}\left({ }^{40} \mathrm{Ar} /\right.$ ${ }^{39} \mathrm{Ar}$-age: Pringle and Duncan, this volume; sedimentary fossil age: Premoli Silva, Haggerty, Rack, et al., 1993; Lincoln et al., 1993). This age is much older than the radiometric K-Ar age of Anewetak (76 Ma; Dalrymple et al., 1975) and the age of the entire Ujlan-Anewetak cluster (75-90 Ma; e.g., Davis et al., 1986; Lincoln et al., 1993), which is indicative of a long and complex volcanic history of the Ujlan-Anewetak cluster. Based on the anomalous older age of Lo-En Guyot, the geometrical complexity of the Ujlan-Anewetak cluster, and the coincidence of this cluster with the southeast end of the Ogasawara Fracture Zone (Fig. 3), we speculate that Lo-En has no obvious hotspot origin but was formed by fracture zone-related volcanism. Plate tectonic reconstructions for Lo-En (using an age of $113 \mathrm{Ma}$ ) indicate that Lo-En was formed significantly south of the currently active Cook/Austral hotspots. This supports the

Table 2. Petrography and setting of Cretaceous seamount samples studied.

\begin{tabular}{|c|c|c|c|c|}
\hline Sample number & Setting & Rock type & Texture & Groundmass \\
\hline \multicolumn{5}{|l|}{ Marshall Islands: } \\
\hline $144-871 \mathrm{C}-35 \mathrm{R}-1,41-43 \mathrm{~cm}$ & South rim edifice & Basanite & Porphyritic, intergranular & Microcrystalline \\
\hline $144-871 \mathrm{C}-38 \mathrm{R}-6,39-43 \mathrm{~cm}$ & South rim edifice & Basanite & Glomeroporphyritic & Microcrystalline \\
\hline \multicolumn{5}{|l|}{ Lo-En: } \\
\hline $\begin{array}{l}\text { 144-872B-9R-2, } 115-120 \mathrm{~cm} \\
\text { Wodejebato: }\end{array}$ & Top edifice & Hawaiite & Trachytic, intersertal & Fine grained \\
\hline $144-873 \mathrm{~A}-17 \mathrm{R}-1,23-27 \mathrm{~cm}$ & Top edifice & Hawaiite & Aphyric, intersertal & Coarse grained \\
\hline $144-874 \mathrm{~B}-24 \mathrm{R}-4,23-25 \mathrm{~cm}$ & Outer northeast rim & Ankaramite & Ankaramite, intergranular & Microcrystalline \\
\hline $144-876 \mathrm{~A}-17 \mathrm{R}-1,98-104 \mathrm{~cm}$ & Outer northeast rim & Alkali basalt & Glomeroporphyritic, intergranular & Medium grained \\
\hline $144-877 \mathrm{~A}-20 \mathrm{R}-5,12-16 \mathrm{~cm}$ & Outer northeast rim & Alkali basalt breccia & Glomeroporphyritic, hyalopilitic & Fine grained \\
\hline TUNES6 9-19 & North slope edifice & Cobble in hyaloclastite & Porphyritic & Microcrystalline \\
\hline TUNES6 $10-1$ & Northeast satellite volcano & Hawaiite & Porphyritic, vesicular ( $20 \%$ ) & Microcrystalline \\
\hline TUNES6 $10-7$ & Northeast satellite volcano & Alkali basalt? & Porphyritic, intersertal & Microcrystalline \\
\hline \multicolumn{5}{|l|}{$\begin{array}{l}\text { Marcus-Wake Seamounts: } \\
\text { MIT: }\end{array}$} \\
\hline $144-878 \mathrm{~A}-80 \mathrm{R}-6.94-98 \mathrm{~cm}$ & Top edifice & Basanite & Glomeroporphyritic, intersertal & Fine grained \\
\hline $144-878$ A-98R-3, $48-53 \mathrm{~cm}$ & Top edifice & Alkali olivine basalt & Microporphyritic, intergranular & Microcrystalline \\
\hline \multicolumn{5}{|l|}{ Japanese Seamounts: } \\
\hline $\begin{array}{l}\text { Takuyo-Daisan: } \\
\text { Tan }\end{array}$ & & & & \\
\hline $144-879 \mathrm{~A}-22 \mathrm{R}-3,99-104 \mathrm{~cm}$ & Perimeter ridge & Alkali basalt breccia & Glomeroporphyritic & Microcrystalline \\
\hline
\end{tabular}

Notes: Setting and petrographic data are after Premoli Silva, Haggerty, Rack, et al. (1993) and this study. Alteration\% is a visual estimate of the modal abundances of secondary phases present in the rock, including those replacing phenocrysts. Sample TUNES6 9-19 is a hyaloclastic pebblestone, from which we analyzed an alkali-basaltic cobble that is less altered than its matrix. NA $=$ not analyzed 
probability for a non-hotspot origin of Lo-En Guyot outside the present-day SOPITA region (Fig. 1).

Twenty-three, late-shield, subaerial flows were recovered from Hole 872B. Sample 144-872B-9R-2, 115-120 cm, from Subunit 17b is a vesicular, trachytic textured, aphyric, fine-grained hawaiite that forms the massive base of a single flow. The lava consists mainly of plagioclase (75 vol\%) and opaque minerals (15 vol\%), with traces of clinopyroxene and apatite. This sample is somewhat more altered (55\% groundmass replacement) than the Limalok samples $(40 \%-$ $55 \%$ ): half of the plagioclase is altered to brown clays and the other primary phases are totally replaced by hematite (opaques) and reddish brown clays.

\section{Wodejebato Guyot}

A ${ }^{40} \mathrm{Ar} /{ }^{39} \mathrm{Ar}$ age of 95 to $93 \mathrm{Ma}$ for the shield-building stage of Wodejebato Guyot was recorded during at Site 869 (ODP Leg 143) on the southwestern volcanic apron (Pringle et al., 1993; Premoli Silva, Haggerty, Rack, et al., 1993). The petrology and geochemistry of these Cenomanian volcanic turbidites are described by Janney et al. (unpubl. data). During Leg 144 (Sites 873 through 877) late volcanic stage, subaerial flows were drilled from the top (or basement) of the Wodejebato volcano to its outer perimeter ridges at the northeast side (Premoli Silva, Haggerty, Rack, et al., 1993). Moreover, a posterosional satellite volcano was dredged during the TUNES6 expedition at the north flank of the main edifice. The ${ }^{40} \mathrm{Ar} /{ }^{39} \mathrm{Ar}$ ages of the Wodejebato volcanic basement lavas range from $78.4 \pm 2.8$ to $85.0 \pm$ $1.5 \mathrm{Ma}$, which is in concordance with all basement lavas being reversely magnitized during the 79-83 Ma 33R chron (Pringle and Duncan, this volume). However, the ages for the satellite volcano may be younger than $80 \mathrm{Ma}$ (Pringle and Duncan, this volume; Koppers and Pringle, unpubl. data). Using a radiometric age of $96 \mathrm{Ma}$ for the main shield-building stage of Wodejebato, the original location of Wodejebato Guyot is very close to that of Lo-En (Fig. 1).

The primary mineralogy of the volcanic flows analyzed is diverse (see Table 2), but they all have moderately alkalic compositions (alkali basalts, ankaramites, and hawaiites). Two samples are plagioclase and clinopyroxene phyric, volcaniclastic rocks: Sample 144-877A-20R-5, 12-16 cm, is a vesicular, alkali basalt breccia, whereas TUNES6 9-19 represents a basalt cobble in a volcaniclastic matrix. About $45 \%$ of the primary mineralogy in Samples 144-873A-17R-1, 23-27 cm, 144-874B-24R-4, 23-25 cm, 144-
876A-17R-1, 98-100 cm, and TUNES6 10-1 has been preserved, with clays and zeolites replacing primary phases only along cracks and rims.

\section{MIT Guyot}

Volcanic flows drilled from the volcanic platform at Site 878 probably resulted from three periods of subaerial, shield-building volcanism, which are separated by distinct weathering horizons: an upper sequence of two hawaiite flows, an middle sequence of basanitoids, and a lower sequence of alkali olivine basalts. The ${ }^{40} \mathrm{Ar} /{ }^{39} \mathrm{Ar}$ ages of Samples 144-878A-80R-6, 94-98 cm, and -98R-3, 48-53 cm, are $121.7 \pm 1.6 \mathrm{Ma}$ and $123.3 \pm 0.9 \mathrm{Ma}$, respectively (Pringle and Duncan, this volume). Pringle and Duncan (this volume) also determined a (slightly younger) weighted best age for MIT: $121.8 \pm 0.5$ Ma. Plate tectonic reconstructions indicate that MIT's original "hotspot" position was close to that of the present-day Tahiti hotspot (Fig. 1), which is in accordance with the reconstructions of Winterer et al. (1993).

Sample 144-878A-80R-6, 94-98 cm, was sampled from Unit 8, a $>10$-m-thick, olivine-phyric (10\%), basanitic flow of the middle section. This rock is relatively unaltered as only $15 \%-30 \%$ of the primary phases are replaced and the groundmass (containing $40 \%$ Ti-augite and $25 \%$ plagioclase) is entirely fresh. Unit 35 of the lowermost basalt flows (Sample 144-878A-98R-3, 48-53 cm) is a very fresh flow ( $>6 \mathrm{~m}$ thick) of alkali olivine basalt with abundant fresh olivine phenocrysts in an intergranular groundmass, dominated by plagioclase. Clinopyroxene $(<10 \%)$, magnetite, and apatite also occur as very fresh phases in the groundmass.

\section{Takuyo-Daisan Guyot}

At Site 879, a 35.5-m-thick, extensively (subaerially) weathered peperite was recovered containing about $20 \mathrm{~m}$ of plagioclase-phyric basalt (Premoli Silva, Haggerty, Rack, et al., 1993). Takuyo-Daisan was covered by calcareous claystones, sandstones, and conglomerates of late Aptian age (Premoli Silva, Haggerty, Rack, et al., 1993), suggesting that this guyot started drowning at least $\sim 116 \mathrm{~m}$.y. ago, which is in concordance with the slightly older ${ }^{40} \mathrm{Ar} /{ }^{39} \mathrm{Ar}$ age of 118 Ma (Pringle and Duncan, this volume). In contrast to the other seamounts studied, Takuyo-Daisan Guyot originated in between the Sa-

Table 2 (continued).

\begin{tabular}{|c|c|c|c|}
\hline Sample number & Phenocrysts & Groundmass phases & $\begin{array}{c}\text { Alteration } \\
\qquad \%\end{array}$ \\
\hline \multicolumn{4}{|l|}{ Marshall Islands: } \\
\hline $144-871 \mathrm{C}-35 \mathrm{R}-1,41-43 \mathrm{~cm}$ & $15 \%$ ol, $5 \%$ Ti-aug & $50 \%$ Ti-aug, $15 \%$ magn, $5 \%$ ne, $5 \%$ pl, $1 \%$ ap & $55 \%$ \\
\hline $144-871 \mathrm{C}-38 \mathrm{R}-6,39-43 \mathrm{~cm}$ & $15 \%$ ol, $5 \%$ Ti-aug & $50 \% \mathrm{Ti}$-aug, $20 \% \mathrm{pl}, 5 \%$ magn, $5 \%$ ne, $2 \%$ ap & $40 \%$ \\
\hline \multicolumn{4}{|l|}{ Lo-En: } \\
\hline 144-872B-9R-2, $115-120 \mathrm{~cm}^{-}$ & None & $75 \% \mathrm{pl}, 10 \%$ magn, $10 \%$ meso, $3 \%$ ilm, $1 \% \mathrm{cpx}$, ap & $55 \%$ \\
\hline \multicolumn{4}{|l|}{ Wodejebato: } \\
\hline $144-873 \mathrm{~A}-17 \mathrm{R}-1,23-27 \mathrm{~cm}$ & $3 \%$ magn, $1 \%$ ol & $40 \% \mathrm{pl}, 20 \% \mathrm{cpx}, 20 \%$ clay, $10 \%$ magn, bio, ap & $30 \%$ \\
\hline $144-874 \mathrm{~B}-24 \mathrm{R}-4,23-25 \mathrm{~cm}$ & $20 \%$ ol, $10 \% \mathrm{pl}, 10 \%$ Ti-aug & $25 \%$ Ti-aug, $25 \% \mathrm{pl}, 10 \%$ magn & $25 \%$ \\
\hline $144-876 \mathrm{~A}-17 \mathrm{R}-1,98-104 \mathrm{~cm}$ & $20 \% \mathrm{pl}, 10 \%$ Ti-aug, $5 \%$ ol & $40 \% \mathrm{pl}, 30 \%$ Ti-aug, $15 \%$ magn, $15 \%$ meso & $55 \%$ \\
\hline $144-877 \mathrm{~A}-20 \mathrm{R}-5,12-16 \mathrm{~cm}$ & $7 \% \mathrm{pl}, 3 \% \mathrm{cpx}$ & $70 \%$ glassy matrix, $20 \% \mathrm{pl}$ & $80 \%$ \\
\hline TUNES6 9-19 & $15 \% \mathrm{cpx}, 8 \% \mathrm{pl}, 2 \%$ ol & $\mathrm{NA}$ & $<85 \%$ \\
\hline TUNES6 $10-1$ & $15 \% \mathrm{pl}, 5 \%$ ol & $40 \% \mathrm{pl}, 15 \% \mathrm{cpx}, 5 \%$ magn & $25 \%$ \\
\hline TUNES6 10-7 & $15 \% \mathrm{cpx}, 4 \% \mathrm{pl}, 2 \%$ ol & NA & $<80 \%$ \\
\hline \multicolumn{4}{|l|}{ Marcus-Wake Seamounts: } \\
\hline MIT: & & & \\
\hline $144-878 \mathrm{~A}-80 \mathrm{R}-6,94-98 \mathrm{~cm}$ & $10 \%$ ol & $40 \%$ Ti-aug, $30 \%$ pl, $10 \%$ op, $10 \%$ ne, $1 \%$ ap & $15 \%$ \\
\hline $144-878 \mathrm{~A}-98 \mathrm{R}-3,48-53 \mathrm{~cm}$ & $10 \% \mathrm{pl}, 3 \%$ ol, $1 \%$ cpx & $50 \% \mathrm{pl}, 20 \%$ ol, $10 \%$ ilm, $5 \%$ meso & $30 \%$ \\
\hline \multirow{2}{*}{\multicolumn{4}{|c|}{$\begin{array}{l}\text { Japanese Seamounts: } \\
\text { Takuyo-Daisan: }\end{array}$}} \\
\hline & & & \\
\hline $144-879 \mathrm{~A}-22 \mathrm{R}-3,99-104 \mathrm{~cm}$ & $25 \% \mathrm{pl}, 1 \% \mathrm{ol}$ & $60 \%$ meso, $10 \% \mathrm{pl}$ & $80 \%$ \\
\hline
\end{tabular}


moa and Marquesas hotspots, from the northern portion of the present-day SOPITA region (Fig. 1).

Sample $144-879$ A-22R-3, 99-104 cm, is a plagioclase-phyric ( $25 \%)$ basalt breccia with a mostly microcrystalline groundmass containing $10 \%$ plagioclase. Nearly half of the plagioclase crystals are cloudy from replacement by zeolites and white clays, whereas the microcrystalline matrix $(60 \%)$ is almost completely recrystallized to reddish brown clay (Premoli Silva, Haggerty, Rack, et al., 1993). About $80 \%$ of this rock is replaced by secondary phases.

\section{METHODS}

Samples were selected to cover all sampled seamounts and guyots using samples for which major and trace element geochemistry is available (Christie et al., this volume). Isotopic analyses were performed exclusively on leached whole rocks (this study).

Rock chips were cleaned of saw marks, wax, and resin using wet silicon carbide sandpaper. These rock chips were precrushed in hardened steel, and ground in a steel ring mortar. The latter was accomplished in small steps of 0.5 to $2 \mathrm{~s}$ alternately with sieving at $250 \mu \mathrm{m}$ until $80 \%-90 \%$ of the rock powder was $<250 \mu \mathrm{m}$. The $<120-\mu \mathrm{m}$ fractions were used for leaching (Table 2), and the 120- to $250-\mu \mathrm{m}$ fractions were reserved for preparing mineral separates. The fine whole-rock fractions were washed and decanted in deionized water three times to remove salts and the fine silt $(<10 \mu \mathrm{m})$.

To remove the effect of seawater alteration, the washed samples were subjected to a leaching procedure that has evolved somewhat from that used by Shimizu and Hart (1973). About $6 \mathrm{~g}$ of sample was leached with $250 \mathrm{~mL}$ ultra-pure $6 \mathrm{~N} \mathrm{HCl}$ for a maximum of $2 \mathrm{hr}$ in an ultrasonic bath. Every $15 \mathrm{~min}$ the rock fraction was stirred, and every $30 \mathrm{~min}$ the acid was replaced. The temperature of the acid solution never exceeded $35^{\circ} \mathrm{C}$. The residues were washed five times in ultraclean water, dried on a hot plate $\left( \pm 70^{\circ} \mathrm{C}\right)$, and checked microscopically for the presence of remaining secondary phases.

Preparation of the rock samples, standard liquid chromatography, and measurements of radiogenic $\mathrm{Sr}, \mathrm{Nd}$, and $\mathrm{Pb}$ isotope ratios were performed at the Laboratory of Isotope Geology, Vrije Universiteit Amsterdam. The isotope compositions were measured on a Finnigan MAT 261 static multicollector system. Sample sizes for Sr, Nd, and $\mathrm{Pb}$ were approximately 1200,1500 , and $20 \mathrm{ng}$, respectively.

\section{RESULTS \\ On the Leaching Procedure}

All of the samples met the following criteria designed to ensure the suitability of altered basaltic rocks for whole-rock leaching and isotopic analysis: (1) more than $30 \mathrm{vol} \%$ of the primary phases (grain size $>10 \mu \mathrm{m}$ ) should have survived alteration; (2) the leaching residue should be coarse enough for microscopic examination to check for residual low-temperature phases; and (3) radiogenic ingrowth from $\mathrm{U}, \mathrm{Th}, \mathrm{Sm}$, and $\mathrm{Rb}$ in the analyzed (mildly) alkalic basalts should have been insignificant (i.e., low parent/daughter ratios), so the measured radiogenic signature is indicative of the initial ratio of the basaltic rock (Staudigel et al., 1991).

Table 2 indicates that for most samples at least $30 \%$ of the primary phases survived alteration, except for the volcanic breccias (Samples 144-877A-20R-5, 12-16 cm, and 144-879A-22R-3, 99-104 cm), which contain $\sim 15 \%-20 \%$ fresh, primary phases. However, microscopic examination showed that for all samples the leaching residue contains no visible secondary phases. The residue normally contains $60 \%-90 \%$ single crystals of primary magmatic phases (clinopyroxene and plagioclase) and $10 \%-40 \%$ composite pieces of single crystals combined with microcrystalline groundmass. The parent/daughter ratios of $\mathrm{Rb}-\mathrm{Sr}$ and $\mathrm{Sm}-\mathrm{Nd}$ (derived from additional Limalok, Lo-En and MIT samples; Christie et al., this volume) are well below 0.055 and 0.185 , respectively, indicating that radiogenic ingrowth was insignificant over the last $\sim 120$ m.y. Determination of U-Pb ratios on samples of a similar basaltic suite by Tatsumoto (see Staudi- gel et al., 1991) indicate that the U-Pb ratios are too low to support any significant radiogenic ingrowth for $\mathrm{Pb}$ over $120 \mathrm{~m}$.y. Thus, on the basis of these three criteria, leaching of these bulk-rock alkalic basalts should provide us with reliable estimates of the initial isotopic composition of the rocks (Table 3 )

Another concern in interpreting the isotopic data is the degree of seawater alteration that may have changed the isotopic signature, in particular that of ${ }^{87} \mathrm{Sr} /{ }^{86} \mathrm{Sr}$. For most of the samples analyzed, much less than $60 \%$ of the primary phases have been replaced by secondary clay, zeolite, and carbonate minerals (Table 2). Previous studies show that secondary phases are effectively removed by leaching (see above), because $\mathrm{Sr}, \mathrm{Nd}$, and $\mathrm{Pb}$ isotopic compositions are consistent between repeated leaching experiments (Staudigel et al., 1991), and because leached whole-rock analyses are similar with fresh glass/ mineral separates (Cheng et al., 1987; Pringle, 1992; Castillo et al., 1992). Nevertheless, severely seawater-altered samples do change element abundances and isotopic compositions with progressive leaching. This is caused by the removal of seawater alteration products and partial dissolution of primary phases, relatively increasing the amount of plagioclase and pyroxene in the residue: $\mathrm{Sm}-\mathrm{Nd}-\mathrm{Rb}$ abundances and ${ }^{87} \mathrm{Sr} /{ }^{86} \mathrm{Sr}$ decrease, whereas $\mathrm{Sr}$ abundances increase (Cheng et al., 1987). Because the leaching procedure is a semiquantitative method, the ${ }^{87} \mathrm{Sr} /{ }^{86} \mathrm{Sr}$ compositions of highly altered basalts (Samples 144-877A-20R-5, 12-16 cm, 144-879A-22R-3, 99-104 $\mathrm{cm}$, TUNES6 9-19A, and TUNES6 10-7) should be close to, but will be a maximum estimate of, its actual value.

\section{Overall Isotopic Variation}

The $\mathrm{Sr}, \mathrm{Nd}$, and $\mathrm{Pb}$ isotopic ratios measured for Limalok, Lo-En, Wodejebato, MIT, and Takuyo-Daisan guyots are listed in Table 3 and illustrated in a ${ }^{87} \mathrm{Sr} /{ }^{86} \mathrm{Sr} v \mathrm{vs} .{ }^{206} \mathrm{~Pb} /{ }^{204} \mathrm{~Pb}$ isotope correlation diagram (Fig. 2). In this diagram, we compare our data to the inferred mantle components after Zindler and Hart (1986), the SOPITA reference fields (Fig. 2A), and other WPSP reference fields (Fig. 2B).

Arrays of SOPITA basalts point toward (1) the highest ${ }^{206} \mathrm{~Pb} / 204 \mathrm{~Pb}$ accompanied by low ${ }^{87} \mathrm{Sr} /{ }^{86} \mathrm{Sr}$ (HIMU), (2) intermediate ${ }^{87} \mathrm{Sr} /{ }^{86} \mathrm{Sr}$ at the lowest ${ }^{206} \mathrm{~Pb} / 204 \mathrm{~Pb}$ (EMI), or (3) the highest ${ }^{87} \mathrm{Sr} /{ }^{86} \mathrm{Sr}$ at low ${ }^{206} \mathrm{~Pb} / 204 \mathrm{~Pb}$ (EMII). Figure 2A indicates that SOPITA basalts do not directly sample DMM (depleted MORB mantle), which is low in both ${ }^{87} \mathrm{Sr} /{ }^{86} \mathrm{Sr}$ and ${ }^{206} \mathrm{~Pb} / 204 \mathrm{~Pb}$ (Zindler and Hart, 1986).

The total isotopic fields of the WPSP and SOPITA regions are comparable in their diversity and in the types of mantle end-members involved, but the most extreme SOPITA end-member values (i.e., HIMU and EMI) have not yet been found in the WPSP (Fig. 2B). The WPSP basalt-isotope compositions presented here cluster at intermediate values when compared to the DMM, HIMU, EMI, and EMII mantle components, and they fall within the range of both the WPSP and SOPITA: ${ }^{87} \mathrm{Sr} /{ }^{86} \mathrm{Sr}=0.70308-0.70486,{ }^{143} \mathrm{Nd} / 144 \mathrm{Nd}=0.51267-$ $0.51307,{ }^{206 \mathrm{~Pb}} / 204 \mathrm{~Pb}=18.58-19.80,{ }^{207} \mathrm{~Pb} / 204 \mathrm{~Pb}=15.55-15.68$, and ${ }^{208} \mathrm{~Pb} / 204 \mathrm{~Pb}=38.68-39.54$ (Fig. 2).

When comparing the isotopic compositions of Cretaceous WPSP basalts with that of the recent SOPITA mantle (Fig. 2B), calculation of the present-day isotopic equivalents for the Cretaceous mantle source is required. Because the hypothetical parent/daughter ratios for the mantle rocks are similar or even lower than those measured from the WPSP basalts (except $\mathrm{Sm} / \mathrm{Nd}$, which may be slightly higher), the radiogenic ingrowth in the ancient WPSP mantle source is negligible (e.g., Staudigel et al., 1991). Therefore, the measured isotopic compositions yield reliable estimates of the present-day mantle source equivalents without performing age corrections.

\section{Marshall Islands}

The Limalok, Lo-En, and Wodejebato basalts display an extensive variation in the $\mathrm{Sr}-\mathrm{Nd}-\mathrm{Pb}$ isotopic systems, but they are nonetheless different from the previously analyzed Marshall Islands seamount basalts (Ratak, Bikar, Erikub, and Majuro: Fig. 3), which show HIMU-like compositions (Staudigel et al., 1991). The new iso- 
Table 3. Sr-Nd-Pb isotope compositions measured from Cretaceous seamounts.

\begin{tabular}{|c|c|c|c|c|c|c|c|c|}
\hline Sample number & Rock type & Type & $\begin{array}{c}\text { Grain size } \\
(\mu \mathrm{m})\end{array}$ & $\begin{array}{l}{ }^{87} \mathrm{Sr} /{ }^{86} \mathrm{Sr} \\
\text { measured }\end{array}$ & $\begin{array}{c}{ }^{143} \mathrm{Nd} / 144 \mathrm{Nd} \\
\text { measured }\end{array}$ & $\begin{array}{l}{ }^{206} \mathrm{~Pb} /{ }^{204} \mathrm{~Pb} \\
\text { measured }\end{array}$ & $\begin{array}{c}{ }^{207} \mathrm{~Pb} /{ }^{204} \mathrm{~Pb} \\
\text { measured }\end{array}$ & $\begin{array}{l}20 \times \mathrm{Pb} / 204 \mathrm{~Pb} \\
\text { measured }\end{array}$ \\
\hline \multicolumn{9}{|l|}{$\begin{array}{l}\text { Marshall Islands: } \\
\text { Limalok: }\end{array}$} \\
\hline $144-871 \mathrm{C}-35 \mathrm{R}-1,41-43 \mathrm{~cm}$ & Basanite & LWR & $<120$ & 0.704437 & 0.512723 & 18.579 & 15.561 & 38.686 \\
\hline $144-871 \mathrm{C}-38 \mathrm{R}-6,39-43 \mathrm{~cm}$ & Basanite & LWR & $<120$ & 0.703549 & 0.512894 & 19.012 & 15.598 & 38.944 \\
\hline $\begin{array}{l}144-872 \mathrm{~B}-9 \mathrm{R}-2,115-120 \mathrm{~cm} \\
\text { Wodejebato: }\end{array}$ & Hawaiite & LWR & $<120$ & 0.704223 & 0.512670 & 19.093 & 15.564 & 39.009 \\
\hline $144-873 \mathrm{~A}-17 \mathrm{R}-1,23-27 \mathrm{~cm}$ & Hawaiite & LWR & $<120$ & 0.704535 & 0.512779 & 19,435 & 15.631 & 39.186 \\
\hline \multirow[t]{2}{*}{$144-874 \mathrm{~B}-24 \mathrm{R}-4,23-25 \mathrm{~cm}$} & Ankaramite & LWR & $<120$ & 0.704851 & 0.512766 & $\begin{array}{l}19.516 \\
10484\end{array}$ & $\begin{array}{l}15.660 \\
15.637\end{array}$ & $\begin{array}{l}39.417 \\
39369\end{array}$ \\
\hline & & $\begin{array}{l}\text { Dupl. } \\
\text { Dupl. }\end{array}$ & & 0.704868 & 0.512770 & $\begin{array}{l}19.484 \\
19.524\end{array}$ & 15.677 & 39.488 \\
\hline 144-876A-17R-1, 98-104 cm & Alkali basalt & LWR & $<100$ & 0.704785 & 0.512767 & 19.440 & 15.648 & 39.299 \\
\hline $144-877 \mathrm{~A}-20 \mathrm{R}-5,12-16 \mathrm{~cm}$ & Alkali basalt breccia & LWR & $<100$ & 0.704688 & $\mathrm{NA}$ & 19.385 & 15.618 & 39.228 \\
\hline TUNES6 $9-19$ & Alkali basalt cobble & LWR & $100-120$ & 0.704441 & 0.512764 & 18.806 & 15.681 & 39.148 \\
\hline TUNES6 $10-1$ & Hawaiite & LWR & $30-60$ & 0.703848 & 0.512756 & 19.491 & 15.631 & 39.546 \\
\hline TUNES6 10-7 & Alkali basalt? & LWR & $30-60$ & 0.703732 & 0.512737 & 19.535 & 15.618 & 39.198 \\
\hline \multicolumn{9}{|l|}{$\begin{array}{l}\text { Marcus-Wake Seamounts: } \\
\text { MIT: }\end{array}$} \\
\hline $144-878$ A $80 \mathrm{R}-6,94-98 \mathrm{~cm}$ & Basanite & LWR & $50-100$ & 0.703083 & 0.512968 & 19.423 & 15.568 & 38.732 \\
\hline $144-878 \mathrm{~A} 98 \mathrm{R}-3,48-53 \mathrm{~cm}$ & Alkali olivine basalt & LWR & $<120$ & 0.703370 & 0.512978 & 19.352 & 15.555 & 38.857 \\
\hline \multicolumn{9}{|l|}{ Japanese Seamounts: } \\
\hline $144-879 \mathrm{~A} 22 \mathrm{R}-3,99-104 \mathrm{~cm}$ & Alkali basalt breccia & LWR & $<100$ & 0.703384 & 0.513069 & 18.216 & 15.432 & 38.020 \\
\hline
\end{tabular}

Notes: Rock types are based on thin-section descriptions (see Table 2 for sources). LWR = leached whole-rock sample, and Dupl. $=$ analysis on a duplicate aliquot of the leached whole-rock sample. Sr and $\mathrm{Nd}$ isotopic mass fractionation corrections are based on ${ }^{86} \mathrm{Sr} /{ }^{88} \mathrm{Sr}=0.1194$ and ${ }^{146} \mathrm{Nd} /{ }^{144} \mathrm{Nd}=0.7219$. The present-day isotope ratios listed are normalized to Vrije Universiteit Amsterdam standard values as follows: for NBS-987 Sr, ${ }^{87} \mathrm{Sr} /{ }^{86} \mathrm{Sr}=0.710269 \pm 19(N=63)$; for Vrije Universiteit standard-VITRON Nd, ${ }^{143} \mathrm{Nd} /{ }^{144} \mathrm{Nd}$ $=0.511336 \pm 9(N=147)$ and for La-Jolla Nd, ${ }^{143} \mathrm{Nd} /{ }^{144} \mathrm{Nd}=0.511852 \pm 7(N=44)$; and for NBS-981 Pb, relative to a mass fractionation of $1.31 \%$ per mass unit. The within-run standard errors on $\mathrm{Sr}$ and $\mathrm{Nd}$ isotope ratios (not listed) are generally smaller than or equal to the reproducibility of the standards. Therefore, absolute accuracies for $\mathrm{Sr}$ and $\mathrm{Nd}$ are as follows: ${ }^{87} \mathrm{Sr} /{ }^{86} \mathrm{~S}=0.000019$, and ${ }^{143} \mathrm{Nd} /{ }^{144} \mathrm{Nd}=0.000009$. Total blanks are $<745$ picograms for $\mathrm{Sr},<7$ nanograms for $\mathrm{Nd}$, and $<250$ picograms for $\mathrm{Pb}$.

topic field for the Marshalls extends from HIMU to halfway toward EMII and, therefore, matches the isotopic field for the Cook/Austral Chain (Fig. 2A).

The two basanites from Limalok Guyot plot toward EMI, at nearly constant ${ }^{206} \mathrm{~Pb} / 204 \mathrm{~Pb},{ }^{207} \mathrm{~Pb} / 204 \mathrm{~Pb}$, and ${ }^{208} \mathrm{~Pb} / 204 \mathrm{~Pb}$. Thus, Limalok has an isotopic signature that partly coincides with the isotopic signature of the currently active Rarotonga hotspot (part of the Cook/Austral Chain). Consistent, but highly variable $\mathrm{Sr}$ and $\mathrm{Nd}$ isotope systematics probably are not caused by alteration, and they represent a variation in the mantle source composition.

Wodejebato Guyot has intermediate ratios for all isotopic systems, and is therefore similar to the high ${ }^{87} \mathrm{Sr} /{ }^{86} \mathrm{Sr}$ fields of the Macdonald and Rurutu hotspots (Cook/Austral Chain). The division of Wodejebato lavas into different groups based on volcanic setting and age is also present in their geochemistry (Fig. 2B). Lavas forming the volcanic basement (studied samples from Leg 144; 85-82 Ma) are higher in ${ }^{87} \mathrm{Sr} /{ }^{86} \mathrm{Sr}$ and slightly higher in ${ }^{207} \mathrm{~Pb} / 204 \mathrm{~Pb}$ and ${ }^{208} \mathrm{~Pb} / 204 \mathrm{~Pb}$. Samples from the posterosional northeast-satellite volcano (TUNES6 $10-1$ and $10-7 ;<80 \mathrm{Ma}$ ) have higher ${ }^{206} \mathrm{~Pb} / 204 \mathrm{~Pb},{ }^{207} \mathrm{~Pb} / 204 \mathrm{~Pb}$, and ${ }^{208} \mathrm{~Pb} /{ }^{204} \mathrm{~Pb}$, and the lowest ${ }^{87} \mathrm{Sr} /{ }^{86} \mathrm{Sr}$ (i.e., they have a more HIMU-like composition). This geochemical age progression toward depleted $\mathrm{Sr}$

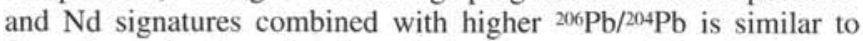
those found for the volcanic evolutionary stages at Hawaii (Stille et al., 1983; Chen and Frey, 1985).

Disturbances by seafloor alteration are most probably insignificant for the Leg 144 basalts and the northeast-satellite volcano, given their internal consistency and the reproducibility from duplicate analysis of Sample 144-874B-24R-4, 23-25 cm. Thus, the variation in isotopic signature for the Wodejebato basalt group most probably reflects primary differences in their mantle source.

\section{Marcus-Wake and Japanese Seamounts}

The MIT and Takuyo-Daisan guyots display low ${ }^{87} \mathrm{Sr} /{ }^{86} \mathrm{Sr}$ and intermediate ${ }^{143} \mathrm{Nd} /{ }^{144} \mathrm{Nd},{ }^{206} \mathrm{~Pb} /{ }^{204} \mathrm{~Pb},{ }^{207} \mathrm{~Pb} / 204 \mathrm{~Pb}$, and ${ }^{208} \mathrm{~Pb} / 204 \mathrm{~Pb}$ signatures. The two samples from MIT only partly fill in the isotopic space between Wilde Guyot and other previously measured Marcus-Wake Seamounts (Lamont, Scripps, and Miami), slightly extending the latter isotopic field toward EMII. The isotopic signature of MIT Guyot is similar only to the low ${ }^{87} \mathrm{Sr} /{ }^{86} \mathrm{Sr}$ lavas of the Marquesas hotspot of the SOPITA. Internal isotopic consistency suggests that seawater alteration was insignificant for these samples, as was expected from their low degree of alteration $(<30 \%)$. Takuyo-Daisan has the most depleted isotopic signature measured relative to the other WPSP seamounts, which is consistent with the trace element geochemistry results of Christie et al. (this volume) and Dieu (this volume).

\section{DISCUSSION}

\section{The WPSP Mantle Source}

Our isotope data provide additional evidence for the anomalously diverse and strongly enriched isotopic signature of the Cretaceous volcanics of the WPSP, as was previously suggested by Smith et al. (1989) and Staudigel et al. (1991). The current WPSP database includes $45 \mathrm{Sr}-\mathrm{Nd}-\mathrm{Pb}$ isotopic analyses from 17 seamounts and guyots (Fig. 2B) that require the involvement of three distinct mantle components: EMI, EMII, and HIMU. These observations indicate that the WPSP mantle source evidently has distinct isotopic properties in comparison to other ocean-island regions or plate tectonic settings. For example, compared to the Cretaceous oceanic plateaus (e.g., Manihiki and Ontong Java) and basins (e.g., Nauru and East Mariana), the WPSP seamounts generally include (1) more extreme EMI and HIMU compositions, and (2) the presence of EMII in their mantle source (Fig. 4).

\section{Comparison with the Present-day SOPITA Mantle Source}

Low ${ }^{87} \mathrm{Sr} /{ }^{86} \mathrm{Sr},{ }^{207} \mathrm{~Pb} / 204 \mathrm{~Pb}$ and ${ }^{208} \mathrm{~Pb} / 204 \mathrm{~Pb}$ in combination with high ${ }^{206} \mathrm{~Pb} / 204 \mathrm{~Pb}$ ratios indicate that part of the WPSP basalts analyzed were formed from an ancient mantle source that definitely included the HIMU component. The isotopic vertical deviations (i.e., delta values) of the WPSP basalts from the Northern Hemisphere Reference Line (NHRL), or from the mantle plane as defined by Hart (1984, 1988) and Zindler et al. (1982), are generally low: (1) $\Delta \mathrm{Sr}<$ 50 , (2) $\Delta 8 / 4 \mathrm{~Pb}$ ranges from -38.5 to 77.7 , (3) $\Delta 7 / 4 \mathrm{~Pb}$ between -3.6 and 14.9, and (4) $\Delta \mathrm{Nd}$ between -200 and 100. These delta values 
A
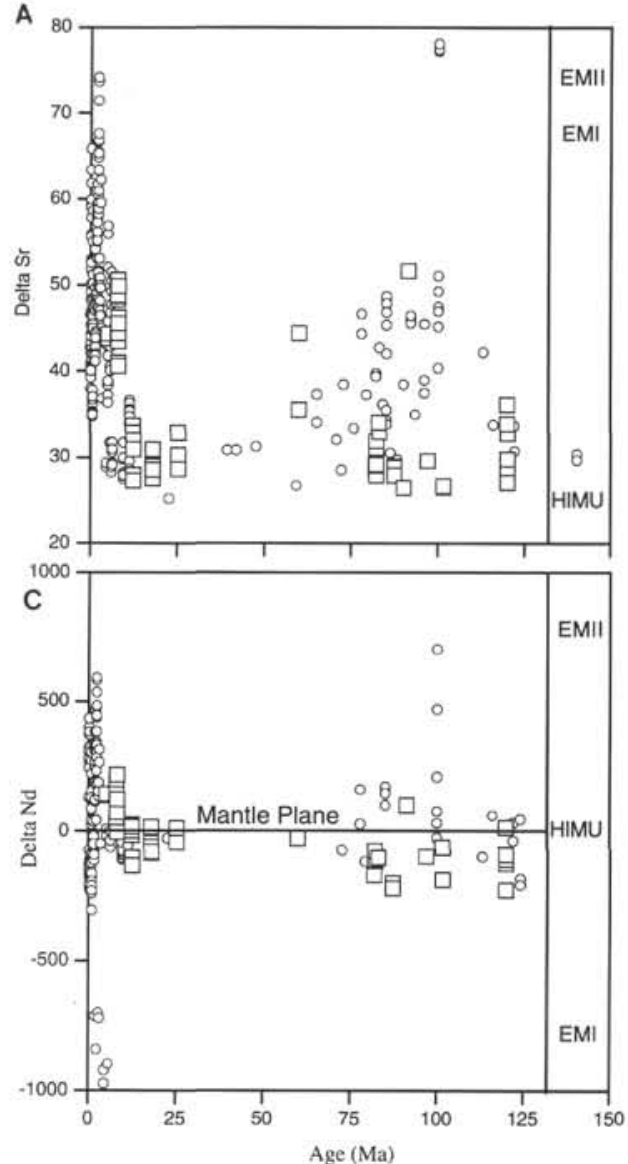

B

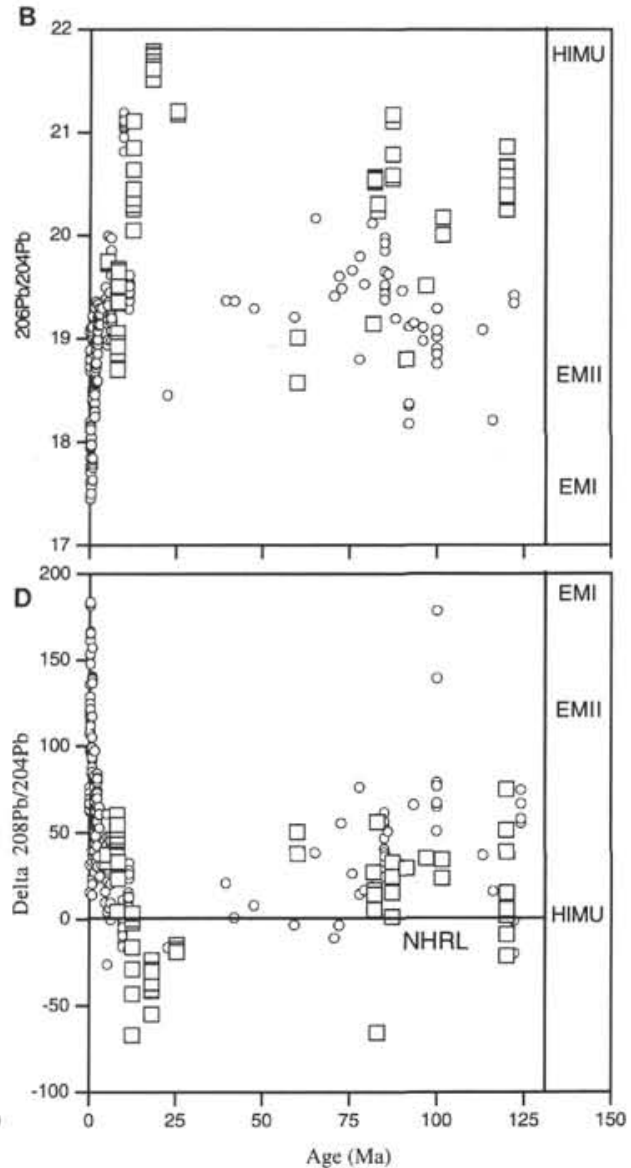

Figure 4. Isotope-geochemical evolution for the Ratak-Marcus-Wake Chain in relation to the Rurutu hotspot and compared to the entire data set of SOPITA and WPSP oceanic-island basalts. For Rurutu, squares represent basalts younger than $25 \mathrm{Ma}$; for the Ratak-Marcus-Wake Chain, squares represent basalts older than $60 \mathrm{Ma}$. Circles represent the balance of SOPITA and WPSP oceanic basalts in all diagrams. The paucity of data between 25 and $\sim 55 \mathrm{Ma}$ indicate a period of decreased volcanic activity. A. Age vs. $\Delta^{87} \mathrm{Sr} /{ }^{86} \mathrm{Sr}$ correlation diagram. The $\mathrm{Sr}$ isotopic composition is expressed as the deviation of the measured ${ }^{87} \mathrm{Sr} /{ }^{86} \mathrm{Sr}$ relative to ${ }^{87} \mathrm{Sr} /{ }^{86} \mathrm{Sr}=0.700$ (Hart, 1984). DMM and HIMU have a near-constant $\Delta \mathrm{Sr}$ value of $25-30$. B. Age vs. $\Delta^{143} \mathrm{Nd} / 144 \mathrm{Nd}$ correlation diagram. $\Delta \mathrm{Nd}$ is defined as the vertical deviation from the mantle plane (Zindler et al., 1982), which includes DMM and HIMU. C. Age vs. absolute ${ }^{206} \mathrm{~Pb} /{ }^{204} \mathrm{~Pb}$ correlation diagram. D. Age vs. $\Delta^{208} \mathrm{~Pb} / 204 \mathrm{~Pb}$ correlation diagram. The $208-\mathrm{Pb}$ vertical deviation is defined relative to the revised Northern Hemisphere Reference Line of Hart (1984), including DMM and HIMU: ${ }^{208} \mathrm{~Pb} /{ }^{204} \mathrm{~Pb}=0.8865\left({ }^{206} \mathrm{~Pb} /{ }^{204} \mathrm{~Pb}\right)+21.700$. The isotopic data is referenced in Figure 2 ; sources for ages can be found in Bergersen (this volume).

characterize the WPSP by a very large total isotopic variance, resulting in an isotopic range between the HIMU, EMII, and EMI mantlecomponents closely resembling that of the present-day SOPITA (Fig. 4 ; cf. Staudigel et al., 1991). However, these delta values are too low to be considered typical to basalts generated from the DUPAL anomaly (Hart, 1984). These observations confirm that the South Pacific mantle has consistently produced melts for the last $120 \mathrm{~m}$.y. that are more extreme and more variable than the DUPAL anomaly, including coexisting HIMU-like volcanics (e.g., Mangaia, Tubuai, HIMU seamount), EMI-like volcanics (e.g., Pitcairn, Rarotonga, Vlinder), and EMII-like volcanics (e.g., Samoa, Hemler). And, indeed, this suggests as well that the DUPAL mantle anomaly is not a globe-encircling mantle anomaly for this period of time, as far as the oceanisland and seamount basalt data sets from the Pacific ocean are concerned.

Within this total compositional range, the isotopic signatures of individual WPSP seamounts correlate with specific SOPITA hotspots, which as well are compatible with their reconstructed, most probable locations of eruption. The Marshall and Magellan seamounts studied originated close to the Rarotonga, Rurutu, and Macdonald hotspots (Cook/Austral Chain), whereas MIT originated near the Tahiti hotspot and Takuyo-Daisan somewhere in between the Marquesas and Samoa hotspots (Fig. 1). These relationships suggest that the isotopically and thermally anomalous mantle source in the
South Pacific should have been active since the Early Cretaceous. Such a long-lived correlation supports the need for a coherent genetic explanation of both features. Recycling of sediments, oceanic crust, or lithospheric mantle (e.g., Chase, 1981; Hofmann and White, 1982; Zindler and Hart, 1986; Farley et al., 1992; Chauvel et al., 1992; Hauri and Hart, 1993) may supply the SOPITA mantle source with an extreme radiogenic signature, as well as with high abundances of heat-producing unstable nuclides (U, Th, K, etc.), anomalously heating up the mantle plume over periods $>100 \mathrm{Ma}$.

\section{Isotopic Evolution of the SOPITA}

Despite the fact that we can trace the SOPITA isotope signature back into the Cretaceous, no well-expressed and long-lived seamount chains (comparable to the Hawaiian-Emperor Chain) have been reported from the southern and western parts of the Pacific Ocean. Assuming that all seamount chains in these regions have been produced by the SOPITA mantle source, SOPITA hotspot activity should have been discontinuous from the Early Cretaceous up to the present day. In fact, seamounts within the WPSP are typically arranged in finite chains (mostly $<20$ m.y. long), as, for example, the Ralik Chain (including Wodejebato Guyot) and the western Ujlan-Anewetak Chain (including Lo-En Guyot) in the Marshall Islands, as well as many unnamed small chains and clusters in the Marcus-Wake, Magellan, and 
Japanese seamounts (see Fig. 3). This observation is compatible with the discontinuous WPSP volcanic activity in the Pacific Ocean basin, as expressed in three distinct pulses: from $\sim 138$ to $90 \mathrm{Ma}$, and from $\sim 83$ to $\sim 65 \mathrm{Ma}$ (Schlanger and Premoli Silva, 1981; Schlanger et al., 1981; Lincoln et al., 1993); and from 20 Ma to the present day in the SOPITA

Bergersen (this volume) reconstructed the hotspot trails for Rurutu and Tahiti back into the Cretaceous, on the basis of stage poles suggested by Duncan and Clague (1985). Using stationary rotation models and the alignment of seamounts, he suggested that the Ratak Chain was produced from the Rurutu hotspot between 74 and 100 $\mathrm{Ma}$, whereas the Marcus-Wake seamount chains were thought to be formed from passing over the Rurutu hotspot at 100-150 Ma (Fig. 3). This reconstructed Rurutu hotspot trail generally is consistent with the available radiometric ages of the seamounts studied. This latter observation is most evident from the marked change of Pacific plate motion at $\sim 100 \mathrm{Ma}$, which for the Rurutu trail coincides in place and time with the bend in the Ratak-Marcus-Wake Chain at the Miami $(97 \mathrm{Ma})$, Wilde $(91 \mathrm{Ma})$, or Lamont guyots $(<87 \mathrm{Ma})$. Following this observation, we consider that the Rurutu, Ratak, and Marcus-Wake chains were continuous, forming the so-called Rurutu-Ratak-Marcus-Wake Chain (RRMW; Fig. 3).

To examine the isotope-geochemical evolution of the Rurutu hotspot over the last 120 m.y., we compared the "modern" Rurutu isotope signatures with those of the "ancient" Ratak-Marcus-Wake Chain. The Cretaceous part of the RRMW Chain may be studied, as (1) the Ratak-Marcus-Wake Chain forms the longest (nearly) continuous seamount trail in the WPSP; (2) the Rurutu hotspot is the most probable source to have produced the chain; (3) the chain includes $\sim 40 \%$ of the WPSP isotopic database; and (4) sufficient radiometric ages are available.

Figures 4A through 4D illustrate the isotopic compositions of WPSP and SOPITA basalts vs. age. Important observations may be made from these diagrams with reference to geochemical variance and evolution over time. The high isotopic variance has remained the same between the present-day SOPITA and its earlier expressions back to $120 \mathrm{Ma}$. Yet, the Ratak-Marcus-Wake Chain displays Sr and $\mathrm{Nd}$ isotopic variations that are smaller than the total variance, but constant over the (time) length of the entire chain. Their isotopic variance is similar to the modern Rurutu hotspot, despite the paucity of data between $\sim 55$ and $\sim 25 \mathrm{Ma}$, indicating both a decreased volcanic activity and a sample bias in the whole Pacific basin. On the contrary, the $\mathrm{Pb}$ composition of individual seamount chains (present-day and Cretaceous) displays large variances including pronounced, systematic geochemical changes. The enhanced diversity in the $\mathrm{Pb}$ composition is dependent on the increased amount of HIMU component involved in the mantle source, which may be indicative of probable extended subduction of oceanic crust over time (cf. Hofmann and White, 1982). This suggests that the Pb system in the mantle may be controlled by different processes over periods of $\sim 100$ m.y. than the $\mathrm{Sr}$ and $\mathrm{Nd}$ systems, which are dependent on sediment recycling (cf. Hart, 1984, and Zindler and Hart, 1986).

Over the last 25 m.y., the ${ }^{206} \mathrm{~Pb} / 204 \mathrm{~Pb}$ isotopes from the SOPITA hotspots display a considerably large decrease that is paralleled by an increase in the $\Delta^{87} \mathrm{Sr} /{ }^{86} \mathrm{Sr}$, a decrease in ${ }^{143} \mathrm{Nd} / 1{ }^{144} \mathrm{Nd}$, and an increase in (negative and positive) $\Delta \mathrm{Nd}$ and (positive) $\Delta 8 / 4 \mathrm{~Pb}$ values (Fig. 4). This directly indicates that the EMI and EMII components have become more important than the HIMU component in the SOPITA mantle source over the last 25 m.y. In general, the trend of this evolution is opposite to that of the isotopic changes with stratigraphy of single volcanoes, as observed for Hawaiian volcanoes that show depletion in their isotopic signatures through time (Stille et al., 1983; Chen and Frey, 1985). Therefore, we infer that the geochemical changes, as described above for the whole group of SOPITA hotspots, are not directed by the stratigraphic development of single volcanoes but by mantle source heterogeneity. This statement is strongly supported by the fact that the compositional evolution has a longer time scale than the maximum $7 \mathrm{~m}$.y. suggested for the duration of single seamount volcanism (cf. Jasper Seamount: Pringle et al., 1991). Alternatively, the observed trend may be explained by sample anomalies, as the presence of extreme stratigraphic designations in this isotopic data set is not assured. We consider this explanation unlikely, because (1) the SOPITA hotspots studied have been extensively sampled, indicating that most of the isotopic variation should be covered; and (2) the scale of the SOPITA region is too large (including eight different hotspots) to resolve any stratigraphic control on the isotopic changes.

The isotopic data set for the Cretaceous seamounts is yet too small to resolve any obvious, short time evolutions. Nevertheless, in the Ratak-Marcus-Wake Chain, the $\mathrm{Sr}$ and Nd isotope compositions systematically seem to decrease in ${ }^{87} \mathrm{Sr} /{ }^{86} \mathrm{Sr}$ and increase in ${ }^{143} \mathrm{Nd} /{ }^{144} \mathrm{Nd}$ between 90 and $70 \mathrm{Ma}$. This variation in $\mathrm{Sr}$ and $\mathrm{Nd}$ composition is accompanied by a sharp decrease in ${ }^{206} \mathrm{~Pb} / 204 \mathrm{~Pb}$ contemporaneous with the decrease of ${ }^{206} \mathrm{~Pb} / 204 \mathrm{~Pb}$ in WPSP oceanic plateaus (Mahoney et al., 1993a, 1993b). In the case of a single hotspot track, this has been explained by a deepening of the mantle source when passing the boundary between the plume head and tail (Mahoney et al., 1993a, 1993b). Deviations from these geochemical trends indicate either (1) renewed volcanism when passing by a second hotspot, (2) deepening of the mantle source sampling different kinds or amounts of mantle components, or (3) volcanism dictated by major tectonic fracture zones (e.g., the Osagawara Fracture Zone: see Fig. 3), which most probably involves shallowing of the source region.

In conclusion, the constancy in variance over the time span of 120 m.y., whether the degree of variance is small or large, and whether it is measured in individual seamount chains or throughout the whole SOPITA and WPSP data sets, seems to be a more intrinsic feature of the SOPITA mantle source than the kinds of mantle components (HIMU, EMI, or EMII) present.

\section{SUMMARY}

We provide $\mathrm{Sr}-\mathrm{Nd}-\mathrm{Pb}$ data on five guyots in the West Pacific, expanding the database to 45 analyses from 17 Cretaceous seamounts. Alkalic basalts drilled from guyots of the WPSP have isotopic compositions similar to those of previously measured basalts, and to basalts from volcanoes in the present-day SOPITA region. We presented an initial discussion on the isotopic evolution of the Ratak-Marcus-Wake Chain in the WPSP, and we compared this to the modern Rurutu hotspot that most likely produced this physical tracer of the Pacific Basin. Based on the alignment and geomorphology of the WPSP seamount trails, their hotspot origin in what is now the South Pacific, and their isotopic signature and variance, we make the following conclusions.

1. The WPSP seamounts are characterized by a large variation in $\mathrm{Sr}, \mathrm{Nd}$, and $\mathrm{Pb}$ isotopic composition involving the EMI, EMII, and HIMU mantle components.

2. Therefore, the WPSP mantle source seems to be similar to the SOPITA mantle source, which appears to have a constant isotopic variance since the Early Cretaceous.

3. The large amount of variation in isotopic composition and the lack of samples with high delta values are indicative of a mantle source more diverse, and therefore possibly more heterogeneous (including HIMU), than required by the mantle source generating the DUPAL region.

4. Relatively small variances for $\mathrm{Sr}$ and $\mathrm{Nd}$ compositions compared to highly variable $\mathrm{Pb}$-compositions suggest that the $\mathrm{Pb}$ system in the mantle may be controlled by different processes over periods of $\sim 100$ m.y. than the $\mathrm{Sr}$ and Nd systems.

5. Hotspots of the SOPITA region show a distinct isotopic enrichment over the last 25 m.y., indicating that their mantle source gradually changed from a HIMU-type to an EM-type over geological time. 
Even though we expanded the WPSP isotopic database significantly, and we provided a more convincing case for the longevity of the SOPITA mantle source region, we still fall short of a comprehensive understanding of the temporal and spatial evolution of hotspot tracks within the West Pacific basin. This is largely because of the very large number of seamounts not yet sampled and the reconnaissance nature of this study.

\section{ACKNOWLEDGMENTS}

We thank Brendan Laurs for helping during sample acquisition and preparation, and Gareth Davies, Richard Smeets, Coos van de Belle, and Frans Benavente for their supervision during the clean-lab and mass-spectrometric analyses. This work was supported by a grant from AWON (NWO) to HS and serves as a part of the Ph.D. thesis of AAPK.

\section{REFERENCES*}

Abrams, L.J., Larson, R.L., Shipley, T.H., and Lancelot, Y., 1993. Cretaceous volcanic sequences and Jurassic oceanic crust in the East Mariana and Pigafetta basins of the Western Pacific. In Pringle, M.S., Sager, W.W., Sliter, W.V., and Stein, S. (Eds.), The Mesozoic Pacific: Geology, Tectonics, and Volcanism. Geophys. Monogr., Am. Geophys. Union, 77:77-101.

Bemis, K.G., and Smith, D.K., 1993. Production of small volcanoes in the Superswell region of the South Pacific. Earth Planet. Sci. Lett., 118:251262.

Castillo, P.R., Carlson, R.W., and Batiza, R., 1991. Origin of Nauru Basin igneous complex: $\mathrm{Sr}, \mathrm{Nd}$, and $\mathrm{Pb}$ isotope and REE constraints. Earth Planet. Sci. Lett., 103:200-213.

Castillo, P.R., Floyd, P.A., and France-Lanord, C., 1992. Isotope geochemistry of Leg 129 basalts: implications for the origin of the widespread Cretaceous volcanic event in the Pacific. In Larson, R.L., Lancelot, Y., et al., Proc. ODP, Sci. Results, 129: College Station, TX (Ocean Drilling Program), 405-413.

Chase, C.G., 1981. Oceanic island Pb: two-stage histories and mantle evolution. Earth Planet. Sci. Lett., 52:277-284.

Chauvel, C., Hofmann, A.W., and Vidal, P., 1992. HIMU-EM: the French Polynesian connection. Earth Planet. Sci. Lett., 110:99-109.

Chen, C.-Y., and Frey, F.A., 1985. Trace element and isotopic geochemistry of lavas from Haleakala Volcano, East Maui, Hawaii: implications for the origin of Hawaiian basalts. J. Geophys. Res., 90:8743-8768.

Cheng, Q., Park, K.-H., Macdougal, J.D., Zindler, A., Lugmair, G.W., Hawkins, J., Lonsdale, P., and Staudigel, H., 1987. Isotopic evidence for a hot spot origin of the Louisville seamount chain. In Keating, B., Fryer, P., Batiza, R., and Boehlert, G. (Eds.), Seamounts, Islands and Atolls. Geophys. Monogr., Am. Geophys. Union, 43:283-296.

Dalrymple, G.B., Jarrard, R.D., and Clague, D., 1975. K-Ar ages of some volcanic rocks from the Cook and Austral islands. Geol. Soc. Am. Bull., 86:1463-1467.

Davis, A.S., Schwab, W.C., and Haggerty, J.A., 1986. Geochemistry and petrology of basaltic rocks from the Marshall Islands. Open File Rep.U.S. Geol. Surv., 86-273.

Duncan, R.A., and Clague, D.A., 1985. Pacific Plate motion recorded by linear volcanic chains. In Nairn, A.E.M., Stehli, F.G., and Uyeda, S. (Eds.), The Ocean Basins and Margins (Vol. 7A): The Pacific Ocean: New York (Plenum), 89-121.

Dupuy, C., Vidal, P., Maury, R.C., and Guille, G., 1993. Basalts from Muruoa, Fangataufa and Gambier islands (French Polynesia): geochemical dependence on the age of the lithosphere. Earth Planet. Sci. Lett., 117:89-100.

Farley, K.A., Natland, J.H., and Craig, H., 1992. Binary mixing of enriched and undegassed (primitive?) mantle components $(\mathrm{He}, \mathrm{Sr}, \mathrm{Nd}, \mathrm{Pb})$ in Samoan lavas. Earth Planet. Sci. Lett., 111:183-199.

Abbreviations for names of organizations and publications in ODP reference lists follow the style given in Chemical Abstracts Service Source Index (published by American Chemical Society).
Garcia, M.O., Park, K.-H., Davis, G.T., Staudigel, H., and Mattey, D.P., 1993. Petrology and isotope geochemistry of lavas from the Line Islands Chain, Central Pacific Basin. In Pringle, M.S., Sager, W.W., Sliter, W.V., and Stein, S. (Eds.), The Mesozoic Pacific: Geology, Tectonics, and Volcanism. Geophys. Monogr., Am. Geophys. Union, 77:217-231.

Hart, S.R., 1984. A large-scale isotope anomaly in the Southern Hemisphere mantle. Nature, 309:753-757.

_ 1988. Heterogeneous mantle domains: signatures, genesis and mixing chronologies. Earth Planet. Sci. Lett., 90:273-296.

Hauri, E.H., and Hart, S.R., 1993. Re-Os isotope systematics of HIMU and EMII oceanic islands basalts from the south Pacific Ocean. Earth Planet. Sci. Lett., 114:353-371.

Hauri, E.H., Shimizu, N., Dieu, J.J., and Hart, S.R., 1993. Evidence for hotspot-related carbonatite metasomatism in the oceanic upper mantle. Nature, 365:221-227.

Hofmann, A., and White, W.M., 1982. Mantle plumes from ancient oceanic crust. Earth Planet. Sci. Lett., 57:421-436.

Lincoln, M.L., Pringle, M.S., and Premoli Silva, I., 1993. Early and Late Cretaceous volcanism and reef-building in the Marshall Islands. In Pringle, M.S., Sager, W.W., Sliter, W.V., and Stein, S. (Eds.), The Mesozoic Pacific: Geology, Tectonics, and Volcanism. Geophys. Monogr., Am. Geophys. Union, 77:279-305.

Mahoney, J.J., 1987. An isotopic survey of Pacific oceanic plateaus: implications for their nature and origin. In Keating, B.H., Fryer, P., Batiza, R., and Boehlert, G.W. (Eds.), Seamounts, Islands, and Atolls. Geophys. Monogr., Am. Geophys. Union, 43:207-220.

Mahoney, J.J., and Spencer, K.J., 1991. Isotopic evidence for the origin of the Manihiki and Ontong-Java oceanic plateaus. Earth Planet. Sci. Lett., 104:196-210.

Mahoney, J.J., Storey, M., Duncan, R.A., Spencer, K.J., and Pringle, M.S., 1993a. Geochemistry and age of the Ontong Java Plateau. In Pringle, M.S., Sager, W.W., Sliter, W.V., and Stein, S. (Eds.), The Mesozoic Pacific: Geology, Tectonics, and Volcanism. Geophys. Monogr., Am. Geophys. Union, 77:233-262.

, 1993b. Geochemistry and geochronology of Leg 130 basement lavas: nature and origin of the Ontong Java Plateau. In Berger, W.H., Kroenke, L.W., Mayer, L.A., et al., Proc. ODP, Sci. Results, 130: College Station, TX (Ocean Drilling Program), 3-22.

McDonough, W.F., and Chauvel, C., 1991. Sample contamination explains the $\mathrm{Pb}$ isotopic composition of some Rurutu island and Sasha seamount basalts. Earth Planet. Sci. Lett., 105:397-404.

McNutt, M.K., and Fischer, K.M., 1987. The South Pacific superswell. In Keating, B.H., Fryer, P., Batiza, R., and Boehlert, G.W. (Eds.), Seamounts, Islands, and Atolls. Geophys. Monogr., Am. Geophys. Union, 43:25-34

Menard, H.W., 1964. Marine Geology of the Pacific: New York (McGraw-Hill).

Ozima, M., Kaneoka, I., Saito, K., Honda, M., Yanagisawa, M., and Takigami, Y., 1983. Summary of geochronological studies of submarine rocks from the western Pacific Ocean. In Hilde, T.W.C., and Uyeda, S. (Eds.), Geodynamics of the Western Pacific-Indonesian Region. Am. Geophys. Union Geodyn. Ser., 11:137-142.

Palacz, Z.A., and Saunders, A.D., 1986. Coupled trace element and isotope enrichment in the Cook-Austral-Samoa islands, southwest Pacific. Earth Planet. Sci. Lett., 79:270-280.

Premoli Silva, I., Haggerty, J., Rack, F., et al., 1993. Proc. ODP, Init. Repts., 144: College Station, TX (Ocean Drilling Program).

Pringle, M.S., 1992. Geochronology and petrology of the Musicians Seamounts: the search for hotspot volcanism in the Cretaceous Pacific. [Ph.D. thesis]. Univ. of Hawaii at Manoa, Honolulu.

Pringle, M.S., and Staudigel, H., 1992. Age and distribution of Cretaceous Pacific Seamount volcanism. Eos, 92:586.

Pringle, M.S., Staudigel, H., Duncan, R.A., and Christie, D.M., 1993, ${ }^{40} \mathrm{Ar} /$ ${ }^{39} \mathrm{Ar}$ ages of basement lavas at Resolution, MIT, and Wodejebato Guyots compared with magneto- and biostratigraphic results from ODP Legs 143/144. Eos, 74:353.

Pringle, M.S., Staudigel, H., and Gee, J., 1991. Jasper Seamount: seven million years of volcanism. Geology, 19:364-368.

Schlanger, S.O., Jenkyns, H.C., and Premoli-Silva, I., 1981. Volcanism and vertical tectonics in the Pacific Basin related to global Cretaceous transgressions. Earth Planet. Sci. Lett., 52:435-449.

Schlanger, S.O., and Premoli Silva, I., 1981. Tectonic, volcanic, and paleogeographic implications of redeposited reef faunas of Late Cretaceous 
and Tertiary age from the Nauru Basin and the Line Islands. In Larson, R.L., Schlanger, S.O., et al., Init. Repts. DSDP, 61: Washington (U.S. Govt. Printing Office), 817-827.

Shimizu, N., and Hart, S.R., 1973. Differential dissolution technics, chemical separation of crystals from glass. Year Book-Carnegie Inst. Washington, 73 .

Smith, W.H.F., Staudigel, H., Watts, A.B., and Pringle, M.S., 1989. The Magellan Seamounts: Early Cretaceous record of the south Pacific isotopic and thermal anomaly. J. Geophys. Res., 94:10501-10523.

Staudigel, H., Park, K.-H., Pringle, M.S., Rubenstone, J.L., Smith, W.H.F., and Zindler, A., 1991. The longevity of the South Pacific isotopic and thermal anomaly. Earth Planet. Sci. Lett., 102:24-44.

Stille, P., Unruh, D.M., and Tatsumoto, M., 1983. Pb, Sr, Nd and Hf isotopic evidence of multiple sources for Oahu, Hawaii basalts. Nature, 304:2529.

Vidal, P., Chauvel, C., and Brousse, R., 1984. Large mantle heterogeneities beneath French Polynesia. Nature, 307:536-538.

Winterer, E.L., Natland, J.H., van Waasbergen, R.J., Duncan, R.A., McNutt, M.K., Wolfe, C.J., Premoli Silva, I., Sager, W.W., and Sliter, W.V., 1993. Cretaceous guyots in the Northwest Pacific: an overview of their geology and geophysics. In Pringle, M.S., Sager, W.W., Sliter, W.V., and Stein, S. (Eds.), The Mesozoic Pacific: Geology, Tectonics, and Volcanism. Geophys. Monogr., Am. Geophys. Union, 77:307-334.
Wolfe, C., and McNutt, M.K., 1991. Compensation of Cretaceous seamounts of the Darwin Rise, northwest Pacific Ocean. J. Geophys. Res., 96:23632374.

Woodhead, J.D., and Devey, C.W., 1993. Geochemistry of the Pitcairn seamounts, I: source character and temporal trends. Earth Planet. Sci. Lett., 116:81-99.

Woodhead, J.D., Greenwood, P., Harmon, R.S., and Stoffers, P., 1993. Oxygen isotope evidence for recycled crust in the source of EM-type ocean-island basalts. Nature, 362:809-813.

Wright, E., and White, W.M., 1987. The origin of Samoa: new evidence from $\mathrm{Sr}, \mathrm{Nd}$, and $\mathrm{Pb}$ isotopes. Earth Planet. Sci. Lett., 81:151-162.

Zindler, A., and Hart, S., 1986. Chemical geodynamics. Annu. Rev. Earth Planet. Sci., 14:493-571.

Zindler, A., Jagoutz, E., and Goldstein, S., 1982. Nd, Sr and Pb isotopic systematics in a three-component mantle: a new perspective. Nature, 298:519-523.

Date of initial receipt: 6 February 1994

Date of acceptance: 13 July 1994

Ms 144SR-031 